\title{
Open for Business: Universities, Entrepreneurial Academics and Open Innovation
}

\author{
Allen T Alexander* \\ Centre for Innovation \& Service Research, University of Exeter \\ Business School, Building One, Streatham Court, Exeter, EX4 4ST, \\ United Kingdom. \\ E-mail: A.T.Alexander@exeter.ac.uk
}

\section{Kristel Miller}

Queen's University Management School, Queen's University Belfast, Riddel Hall, 185 Stranmillis Road, Belfast, BT9 5EE, Northern Ireland. E-mail: kristel.miller@qub.ac.uk

\section{Sean Fielding}

Research \& Knowledge Transfer, University of Exeter, Innovation

Centre, Rennes Drive, Exeter, EX4 4RN, UK

E-mail: s.n.fielding@exeter.ac.uk

* Corresponding author

\begin{abstract}
This is an example of the abstract style. The abstract should be between 100 and 150 words.

Keywords: University; Open Innovation; Entrepreneurs; Business Development; Knowledge Transfer; Intellectual Property; Governance.
\end{abstract}

\begin{abstract}
The emergence of open innovation theory and practice, alongside the evolution to a quadruple helix system of innovation, has led to a need for universities to rethink their models of engagement with industry and wider society. One important element in this system is the entrepreneurial academics; however there is a lack of research considering the motivations of entrepreneurial academics, who differ from academic entrepreneurs, to engage in knowledge transfer in line with open innovation policy. This research offers practical insights on whether new models of engagement, increasingly offered by universities, really address the policy drivers for open innovation. Furthermore, this research explores whether these activities motivated entrepreneurial academics. Preliminary findings identify that a large number of collaboration activities do not motivate entrepreneurial academics. This may have important implications on the ability of universities to become truly open and to encourage their academics to become engaged in collaboration and impact.
\end{abstract}




\section{Introduction}

In the classical triple helix view of university-government-industry engagement (Etzkowitz, 2002) universities and higher education are placed as one contributing element in a knowledge society - or as more recently presented, within a 'system of innovation'(OECD, 1997; RIS, 2014). In moving to a quadruple helix view, where end-users are positioned alongside universities, government and industry to represent more "open" modes of innovation (Carayannis and Campbell, 2012), the role that universities play in this activity or system of activities is reaffirmed. Whilst a quadruple helix system of innovation depicts a set of interdependent entities collaborating (Carayannis and Rakhmatullin, 2014), University funding is increasingly reliant upon industry and end-user engagement to demonstrate their ability to contribute to economic development (McAdam et al., 2012). Therefore, universities have a distinct role to play in these systems of innovation (Howells et al., 2012; Dowling Report, 2015) where the responsibility firmly rests with universities and other publicly-funded research organisations to consider what they offer, how it is packaged, how organisations and end-users adopt and internalise it and to review this offering to establish if this could be improved as times change.

One of the core premises of a quadruple helix system of innovation, which also reflects how the commercial world is changing, is the need for "unconstrained flows of knowledge" (Chesbrough, 2003) between collaborating partner organisations (Carayannis and Campbell, 2012; Leydesdorff, 2012). This reflects the rise in importance of open innovation processes. Gassman and Enkel, (2004) identify that three are three types of open innovation processes, inside out, outside in or a combination of inside out and outside in processes. The engagement in open innovation processes is said to "accelerate internal innovation, and expand the markets for external use of innovation, respectively" (Chesbrough, 2006:2). Organisations working in an open innovation paradigm, regardless of whether the process and/or the outcomes are open or closed (Huizingh, 2011), require partnerships and high value relationships that enable this free flow of information and knowledge (Arnkil et al., 2010; Chesbrough, 2010). Universities and public research organisations offer possible partners for organisations - either partially or entirely replacing the traditional roles of in-house research and development functions. However, policy-level studies across the world show that whilst this might be a powerful economic imperative, the success of university-industry engagement varies considerably (Perkmann and Walsh, 2007; Perkmann et al., 2013), with a recognition across Europe that the activity underperforms (Witty Review, 2013; Dowling Report, 2015).

To attempt to redress the underperformance of knowledge transfer activities, Universities now commit considerable resources in their Knowledge Transfer or Technology Transfer Offices to enable them to broker knowledge and establish partnerships, acting in the role of intermediary (Howells, 2006; Yusuf, 2008; Galbraith and McAdam, 2013; Perkmann and Schildt, 2015).University 
Knowledge Transfer offices are responsible for deriving schemes, some of which are aimed at stimulating open innovation or are particularly attractive to certain groups of academics, but these schemes are often a revised version of their existing schemes 'rebranded'. Little is known about the "Entrepreneurial Academic" and in particular how and why they choose the modes of engagement that they do (Perkmann et al., 2013; Perkmann et al., 2015). This lack of research is surprising considering academics are a core determinant of the success of knowledge transfer and open innovation practice and are a core actor in an effective quadruple helix innovation system. Accordingly, this research offers practical insights on whether some of the 'new' models of industry engagement increasingly offered by universities really address the drivers for open innovation and collaboration. Furthermore, this research explores whether these services are suitably rewarding and motivate academics to engage and to become the "Entrepreneurial Academics" who are often referred to in policy documents, strategic visions and common-room rhetoric.

This paper makes several contributions. First, within the innovation management community there is an acknowledged shortfall of research that explores the management of knowledge flows in an open innovation paradigm (Enkel et al., 2009), both between organisations and across organisational /research boundaries (Padilla-Melendez and Garrido-Moreno, 2011; Howells et al., 2012). This research extends knowledge and understanding by considering which types of university engagement satisfy the drivers for open innovation as dictated by government policy. Second, prior studies often take a macro approach to explore open innovation; however, this research adopts a micro level of abstraction by exploring Entrepreneurial Academics who are individual actors within open innovation projects (Perkmann et al., 2013). This brings into consideration the importance of individual contributors to this open innovation activity, in this case the academics within the universities. From a practical perspective this research will help practitioners (such as University senior managers, or knowledge brokers and intermediaries) to understand how university offerings can contribute or detract from the open innovation imperative. It will also aid practitioners in understanding how they can stimulate the participation of academics to become Entrepreneurial Academics within their organisations.

\section{The Perspective from the Literature}

Transition from triple to quadruple helix: The need for more open models There have been numerous studies of the triple helix of industry-governmentacademic engagement since the concept was first introduced at the end of the $20^{\text {th }}$ Century (Lawler, 2011; Leydesdorff, 2012). Typically these studies consider the policy or systems-level interaction, or focus on the relationships and interactions between the organisations (Alexander and Childe, 2011). In recent years, it has been suggested that this normative model has discouraged open flows of knowledge and engagement between industry-government and academics 
(PACEC, 2012). Indeed, industrial partners claim that universities have become overly protective of their intellectual property rights arising from knowledge transfer activities (Siegel et al., 2004) and institutional bureaucracy has been found to often discourage open innovation practices (Hewitt-Dundas, 2012; Van Looy, 2011). Moreover, Kenney and Mowery (2014) note triple helix based stakeholder engagement can lead to knowledge transfer based on bi-directional flows of knowledge as opposed to a more co-creational open innovation focused approach. These criticisms coupled with many universities underperforming in terms of expected innovation (Witty Review, 2013; Dowling Report, 2015) has placed emphasis on the need for a quadruple helix system of innovation (Carayannis and Campbell, 2009; Carayannis and Rakhmatullin, 2014). To date there are a limited number of studies to date exploring quadruple helix based models of innovation and engagement reflecting the emergent nature of the field. Any studies which do exist have a bias toward the systems, policy or organisational level of abstraction. For example, a macro level perspective by Schoonmaker and Carayannis (2013) identifies that despite pressure from national innovation policy most universities appear to be still operating within triple helix structures and are failing to develop expected levels of collaboration with industry and end users. MacGregor et al., (2010) identifies that challenges in universities adopting more open knowledge transfer models lie at both a regional and sector level. Their study on the Quadruple Helix readiness of 16 European cities identifies that regions dominated by companies which produce commodes or by low technology smaller companies, there is often a lack of absorptive capacity or motivation for companies to collaborate with universities. Whilst research to-date does recognise that there are several drivers which dictate engagement in open innovation practices between quadruple helix stakeholders (Arnkil et al., 2010; MacGregor et al., 2010; Plewa, 2013), a limited number of studies actually explore the interaction and motivations of individuals at a micro level. Colapinto and Porlezza (2012) notes that a quadruple helix system depends on not only 'hard' infrastructure and macro level systems but that the 'soft infrastructure' at an individual level, such as the knowledge transfer mechanisms and human capital are just, if not more, important.

It is recognised that an effective and fully functioning quadruple helix requires universities to adopt more open models of knowledge transfer where industry and end users are engaged at all levels (Arnkil et al., 2010; Miller et al., 2014). University engagement with industry is reliant upon a range of actors, such as business liaison staff and knowledge transfer staff but a key actor in the process is the academic.

\section{Introducing the Entrepreneurial Academic}

One of the most important micro level antecedent for a functioning quadruple helix is the provision of Entrepreneurial Academics (MacGregor et al., 2010; Miller et al., 2014). Universities are reliant upon the motivation of academics to engage in entrepreneurial activities and open innovation with external stakeholders in order 
to fulfil their remit of becoming an 'entrepreneurial university'. In literature, an Entrepreneurial Academic is recognised to be different from an Academic Entrepreneur. An Academic Entrepreneur typically describes an academic who engages in formal commercialisation activities which often result in patents creation, license sales and/or the creation of new ventures and spin out firms (Jensen and Thursby, 2001; Shane, 2004), whereas an Entrepreneurial Academic is deemed to participate in a wider range of engagement, collaboration and knowledge transfer activities linking the university with other organisations, mostly notably industry (Meyer, 2003; Bicknell et al., 2010; Perkmann et al., 2013). An entrepreneurial academic is said to be involved in activities which involve personal interactions with industry (Cohen et al., 2002) which often have a wider goal than conducting research for only publishing purposes and may result in financial or non-financial benefits (Perkmann and Walsh, 1999. The activities performed by the entrepreneurial academic have been found to be more valuable by industry than university patents (Perkmann et al., 2013. To date there is a lack of research exploring the motivations of the entrepreneurial academic in contrast to those of an academic entrepreneur. An exploratory study by Bicknell et al., (2010) identifies that an entrepreneurial academic has different values where they are not based on contractual obligations and are instead motivated by recognition that their research had a wider purpose in society. However, Perkmann et al., (2013) review of academic engagement identifies that the entrepreneurial academic is often driven by research related motivations where it is seen as an extension to their current role and can lead to access to resources, funding and learning opportunities. Within literature it is identified that the engagement activities carried out by an entrepreneurial academic may lead to commercialisation activities through co-development of innovation that can be patented, licenced or formed into spin out companies or joint ventures (Meyer, 2003; Perkmann et al., 2013). This can lead to a transition from an entrepreneurial academic to an academic entrepreneur. However, many academic entrepreneurs never engage in relational engagement activities and in some cases, thus the two concepts can be viewed as a continuum. Figure 1 presents this continuum.

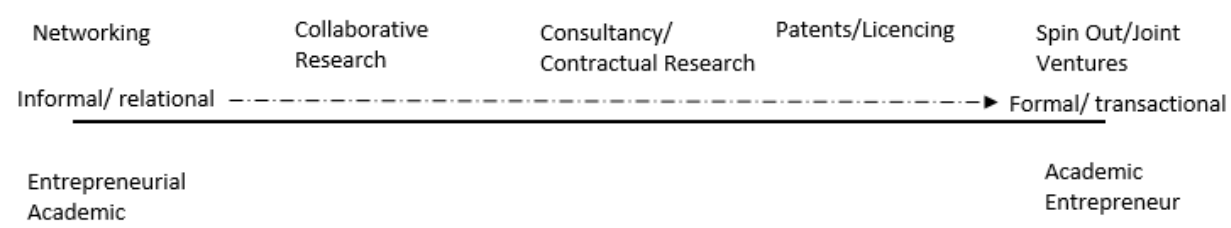

Figure 1: Continuum of Entrepeneurial academic and Academic Entrepreneur

Prior research identifies that modes of university engagement with industry and end-users are varied however, studies often focus on formal interactions during technology commercialisation activities such as patenting, licencing and spin out 
companies (Rothaermel et al., 2007; Grimaldi et al., 2011). Indeed, Perkmann et al. (2013) note that other forms of interaction such as collaborative/contract research, consulting and other forms of tacit knowledge exchange which arise from day to day informal interactions such as guest speakers, seminar events, often remains hidden in the background but can be a vital source of knowledge exchange (Perkman and Walsh, 2007; Martinelli et al., 2008; Ponomariov, 2008). Alexander \& Childe (2012) build on the work of previous researchers (Agrawal, 2001, Schartinger et al., 2002, Holi et al., 2007) to present a synthesised, common framework of 13 modes or models for engagement, which they refer to as the channels of knowledge transfer. These channels of knowledge transfer are categorised according to the level of governance reflecting the variances in types of university knowledge transfer (see appendix 1).

\section{Entrepreneurial Academics' Motivation}

Numerous studies identifies that there are multiple, often conflicting demands on an Entrepreneurial Academic's time and given the considerable distance between typical industry and academic knowledge frontiers, significant effort is required to develop successful collaborative relationships (Rothaermel et al., 2007; Perkmann and Walsh, 2007; Shibayama, 2012). It is widely reported within literature that university engagement with industry is underpinned by conflicting demands of teaching, research and academic enterprise with studies reporting the resource pressure academics face in balancing their academic remit (Rasmussen and Borch, 2010; Miller et al., 2014). Hohman and Fuller (2010: 2) note that "academics have been traditionally conditioned to view their main professional objective as teaching and research publications" where it is only recently that external engagement has been seen as a key element of an academics role.

Bicknell et al., (2010) identifies that research to date predominantly focuses on the challenges of university-industry collaboration however, there is a lack of research which explores the micro-level motivation of Entrepreneurial Academics. Within literature, several studies allude to the motivations of academics to engage with industy however, the results are inconclusive (Bicknell et al., 2010). Research by D'este and Perkmann (2010) identify that the primary motivation for academics to engage with industry is to further research related activity. Other reasons cited in literature are to gain recognition and academic esteem from peers (Grimpe and Frier, 2010), gain a financial reward (Lockett et al., 2008; Bercovitz and Feldman, 2008), provide academic contribution (Lee, 2000; D'este and Perkmann, 2011), to learn from and gain feedback from industry partners (Meyer-Krahmer and Schmoch 1998; D'este and Perkmann, 2010) and to make a tangible contribution to society (Bicknell. 2010). Perkman et al., (2013) review summates that Entrepreneurial Academics' engagement with external sources of knowledge is reliant upon a wide range of factors, namely; individual characteristics (e.g. demographics, career trajectory, productivity, attitudes motivation and identity), the organisational context (technology transfer support, formal incentives, 
department quality and department climate) and institutional factors (such as disciplines, regulation and public policy). Furthermore, Lam (2011) suggests that the intrinsic and extrinsic motivation for engaging with industry varies according to academics attitudes and values.

The Dowling Report 2015 identifies that collaboration with industry can often involve considerable time and resources as a result of complex or bureaucratic government schemes or the need to build up trust and repoir, which often detracts the attractiveness of academics engaging in such activities. Consequently, it is evident that a the motivations of entrepreneurial academics is embedded within organisational, institutional and macro level factors affecting both their resources and motivation to interact effectively with industry and end-users (Perkmann et al., 2013; Miller et al., 2014) which may hinder the realisation of quadruple helix structures.

\section{Development of Research Questions}

From prior research, it is evident that the transition from a triple helix to a quadruple helix system of innovation has seen the need for universities to rethink their traditional knowledge transfer processes to more fully engage with industry and end users (Carayannis and Rathmullin, 2014). This is coupled with the trend for industry to engage in more open innovation practices, where universities are seen as key partners to aid research and development efforts (Arnkil et al., 2010). Furthermore, recent open user-centric policy (RIS, 2014) and changes to university funding mechanisms has seen the need for universities to progress from a largely knowledge push and a linear model of knowledge transfer and innovation, to more collaborative and open models (Witty, 2013; Miller et al., 2014). However, due to the emergent nature of these practices there are a lack of research which explores these new open models and services from universities and whether they are in line with the demands of recent innovation policy.

This led us to our first research question:

1) Does the new style of open innovation services increasingly offered by universities really address the drivers for open innovation and collaboration with quadruple helix stakeholders dictated by recent innovation policy?

As identified, the Entrepreneurial Academic is a core stakeholder in a quadruple helix system of innovation. Universities are reliant upon the motivation of academics to participate in quadruple helix stakeholder collaborations and to engage in open innovation with industry. However, there is a lack of research which explores what motivates academics to become an Entrepreneurial Academic. This leads us to our second question. 
2) Are these new services suitably rewarding and motivate academics to engage and to become the "Entrepreneurial Academics" who are often referred to in policy, strategy and rhetoric.

\section{Data Collection and Analysis}

This exploratory research follows Yin (2011) who suggests using an inductive approach in order to help build theory in a sense making manner. In order to identify the range of services which universities appear to offer, organisations who are members of PraxisUnico ${ }^{1}$ were asked to identify the range of channels that they used to engage with universities. 50 Organisations responded in two waves of data collection. The first originated from a cohort of delegates attending a focussed development event and then second, as a selective group of board members and affiliates of PraxisUnico. This raw data was then cleaned and combined to create a list of engagement and innovation activities which was entered into a proforma comprising of consistent headings and explanatory detail. A copy of this is provided in Annex 1.

To aid the sense making approach (Gephart, 1993) an iterative process of analysis was carried out involving constant referral back to the literature to help understand and analyse data (Yin, 2011). This comprised of three stages.

Step 1 - The engagement activities were mapped onto the list of channels of knowledge transfer, provided by Alexander and Childe (2012), to establish if there were any entirely new modes of engagement.

Step 2 - The new engagement activities were then considered in terms of the primary drivers for Openness, as presented in Alexander et al (2012) and their research instrument was applied to establish if these channels presented a different degree of openness, set against their original spectrum which ranged from 100\% Open to Knowledge Transfer Capable.

Step Three - The categories for engagement were mapped against a priori concepts (Yin, 2011) related to the motivations to become an Entrepreneurial Academic as derived from the literature. These a priori concepts derived from the literature which were academic promotion / coverage in the media / academic esteem (with peers etc.) / motivation to create a tangible contribution to society / respect from industrial partners / pay (or other direct financial reward) ( Tornatzky et al., 2002; Siegel et al., 2004; Goktepe and Mahangaonkar, 2008; D'Este and Perkmann, 2010; Perkmann et al., 2013).

\footnotetext{
${ }^{1}$ PraxisUnico are a member-based organisation based in the UK, who comprise of university knowledge transfer, technology transfer or arms length commercialisation companies whose aim is to commercialise research and create impact from their host institutions.
} 
The aim of the second and third steps of the analysis was to consider how the recent modes of collaboration might "stimulate and motivate the Entrepreneurial Academic" as opposed to primarily rewarding the institution, the contributing partners or users (in the quadruple helix model). The purpose of this final comparison was to establish if traditional "closed" innovation service offerings are more or less attractive when compared to "open" innovation offerings to a hypothetical "Entrepreneurial Academic".

To present the findings and to aid analysis a simple coding technique was used to create a primary ranking of the channels (Adapted from Alexander and Martin, 2013), where a positive indication was marked with +1 , a negative indication marked with -1 and an ambiguous or mixed response was given 0 . The results of this ranking is shown in Table 1.

\section{The findings}

From the findings, it was identified that there was both consistencies and inconsistencies across the respective knowledge transfer channels as defined by Alexander and Martin (2012). In relation to the first step of analysis, 'whether there were any modes of engagement that fell outside of the definitions provided by Alexander and Childe, (2012)', the data collected unfortunately did not find any additional new and open modes of collaboration. The 'networking' channel of knowledge transfer appeared to be 'repackaged' as several modes of collaboration but were in fact different types of networking events. For example, under networks, there was the emergence of 'Themed Events', 'Business Leaders Forum's', 'Innovation Clubs', 'Industry Engagement Forums', 'Study Groups' and 'Twitter Events'. Under the consultancy and contract research knowledge transfer channel, there was the addition of 'innovation vouchers' which are a UK government run initiative where government funds up to $£ 5000$ to pay for an external expert (often an academic) to aid innovation activities (InnovateUK, 2015). Furthermore, under the joint supervision channel, Knowledge Transfer Partnerships were identified as a mode of collaboration. These additional modes of collaboration, still fall under Alexander and Martins (2013) defined knowledge transfer channels therefore do not represent entirely new modes of collaboration and are variations of existing knowledge transfer channels.

Interestingly there were two categories reported in Alexander and Childe (2012) that were not reported in the recent findings, namely Joint Journal Publications and Joint Ventures signalling a lack of engagement by industry within these channels of knowledge transfer.

In respect to the second step of the analysis, 'the evaluation of the openness of the modes of engagement,' there was some consistency with Alexander and Martin's (2013) results with all of the 'repackaged' modes of engagement within the knowledge transfer channel ranking as open (between +4 and +7 ). Student Placements, Joint Supervision and Secondments also returned consistent scores to 
those reported by Alexander and Martin (2013) in terms of being open (ranging between +1 and +6$)$, with Funded Chairs being the least open $($ at +1$)$.

Collaborative Research also presented open levels of engagement (ranging from $(+3$ to +7$)$. In terms of consistency, the channels Contract Research and Consultancy and the new variants of this activity were all ranked as being quite closed, in terms of open innovation (between -8 and -4 ).

Moving toward stage 3, mapping the new modes of engagement against the motivations of Entrepreneurial Academics, there are some consistencies across the results, in terms of their channel origins, but it is more subtle. The most significant finding is that new Student Placement modes of engagement do not appear to be attractive for Entrepreneurial Academics (ranking consistently at -7). Training and CPD activities do not appear to be high in terms of motivation either $(-3 \&-4)$, however Open Programmes appeared to be marginally more interesting than Closed Programmes. 
Table 1 The comparison of openness and channels that motivate Entrepreneurial Academics

\begin{tabular}{|c|c|c|c|c|}
\hline $\begin{array}{c}\text { Channel of } \\
\text { Knowledge } \\
\text { Transfer }\end{array}$ & $\begin{array}{l}\text { PRAXIS UNICO } \\
\text { Survey (2014) }\end{array}$ & $\begin{array}{c}\text { Relational vs. Transactional } \\
\text { *(Alexander \& Martin, 2013) } \\
\text { Transactional } \\
\text { Relational }\end{array}$ & $\begin{array}{c}\text { Degree of Openness } \\
\text { Closed } \\
\text { Open }\end{array}$ & $\begin{array}{c}\text { Degree of Motivation for } \\
\text { Entrepreneurial Academics } \\
\text { Low } \\
\text { High }\end{array}$ \\
\hline & & $\begin{array}{ccc}-5 \leftarrow & 0 \\
& +5 & \\
\end{array}$ & $\rightarrow+10$ & $\rightarrow+7$ \\
\hline \multirow{3}{*}{ Shared Facilities } & Pro-Bono Time & \multirow{3}{*}{$(-2)$} & $(0)$ & \multirow[b]{2}{*}{$(+2)$} \\
\hline & Shared facilities & & $(-4)$ & \\
\hline & Material Transfer Agmts. & & $(+2)$ & $(-3)$ \\
\hline Joint Conference & Study Groups & $(+2)$ & 】(+5) & 】(+3) \\
\hline Spin-outs & Commercial Opps. & $(-1)$ & $(-2)$ & $(0)$ \\
\hline P. Journal Pubn. & None Presented & $(+4)$ & & \\
\hline \multirow{2}{*}{ Networks } & Themed Events & \multirow{2}{*}{ | $(+3)$} & $(+6)$ & $(+1)$ \\
\hline & Business Leaders Forum & & $+4)$ & $(-2)$ \\
\hline \multirow[t]{2}{*}{ Training \& CPD } & Open Exec. Education & \multirow[t]{2}{*}{ 】(+1) } & $(+7)$ & $(-3)$ \\
\hline & Customised Programmes & & $(-7)$ & $(-4)$ \\
\hline \multirow{3}{*}{$\begin{array}{l}\text { Cont. Res. \& } \\
\text { Consult. }\end{array}$} & Consultancy & \multirow{3}{*}{$(-3) \square$} & $(-8)$ & $(+4)$ \\
\hline & Contract Research & & $(-8)$ & \multirow[t]{2}{*}{$(+1)$} \\
\hline & Innovation Vouchers & & $(-4)$ & \\
\hline \multirow{2}{*}{$\begin{array}{l}\text { Student } \\
\text { Placements }\end{array}$} & Student Volunteering & \multirow{2}{*}{ (0) \} $&{(+6)} &{\multirow{2}{*}{\frac{(-7)}{(-7)}}\frac { ( - 7 ) } { ( - 7 ) }} \\
{\hline} &{\text { Graduate Recruitment }} &{ } &{(+2)} &{ } \\
$\hline}
\end{tabular}




\begin{tabular}{|c|c|c|c|c|}
\hline & Student Business Projects & & $(+3)$ & 7) \\
\hline & Graduate Bus. Projects & & $(+4)$ & 7) \\
\hline \multirow{3}{*}{ Joint Supervision } & $\begin{array}{l}\text { Masters' Training } \\
\text { Scheme }\end{array}$ & \multirow{3}{*}{$\mathbf{I}(+3)$} & I $(+4)$ & $(-4) 【$ \\
\hline & Industrial CASE PhD & & T(+6) & (0) \\
\hline & $\begin{array}{l}\text { Knowledge Transfer } \\
\text { Ptns. }\end{array}$ & & I $(+2)$ & $\mathbf{I}(+3)$ \\
\hline
\end{tabular}

Table 1 (Cont.) The comparison of openness and channels that motivate Entrepreneurial Academics

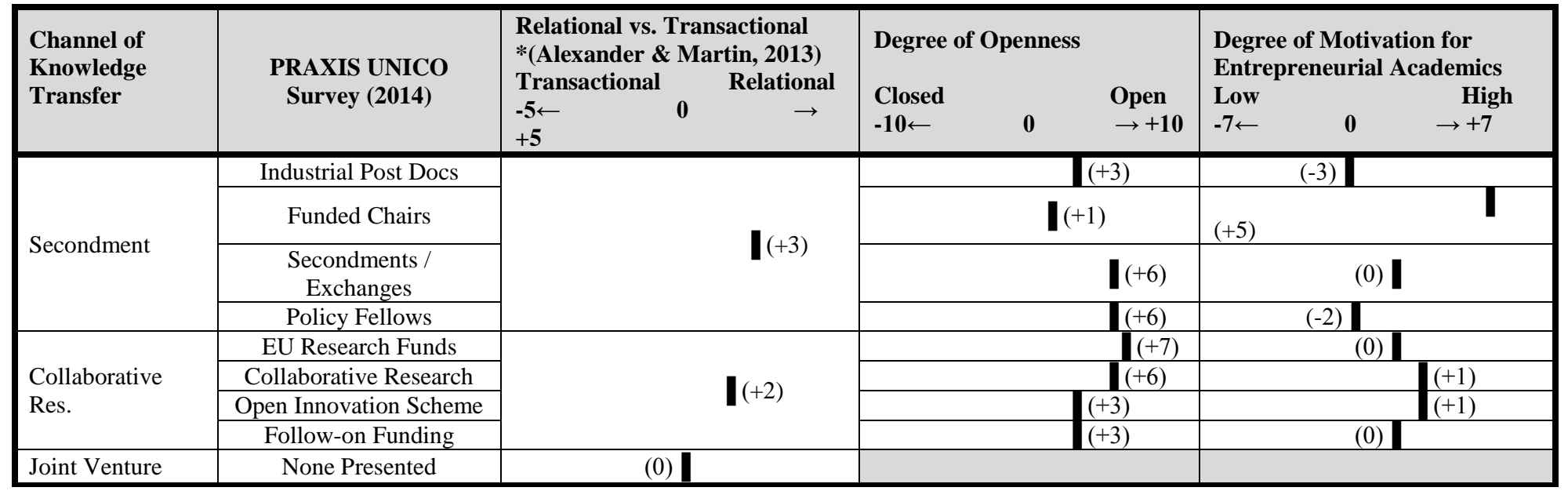

*Source: Adapted from the original work of Alexander \& Martin, 2013. 
Contract Research and Consultancy modes of engagement provided some degree of motivation (ranging from 0 for Innovation Vouchers to +4 for Consultancy). Likewise, but to a lesser degree, Collaborative Research activities presented some motivation (scoring between 0 and +1 ).

The other categories, such as Shared Facilities, Joint Supervision and Secondment all provided relatively low levels of motivation, with only 'Knowledge transfer Partnerships' (+3) and 'Shared Facilities' (+2) providing some motivation for entrepreneurial academics.

\section{Discussion}

By constructing a basic analysis of the openness of knowledge transfer channels and by then considering how motivated a hypothetical Entrepreneurial Academic becomes in wishing to undertake these activities we can make some observations.

The range of new modes of collaboration for networking (Themed Events, Business Leaders Forum's, Innovation Clubs, Industry Engagement Forums, Study Groups and Twitter Events) are focussed on an open innovation style engagement, which are said to stimulate long term relationships between organisations who participate. This is consistent with the view of Perkmann and Walsh (2008) who suggest partnering stimulates long term, trust-based relationships which can lead to open knowledge sharing and is consistent with the view in literature or an entrepreneurial academic being engaged in relational knowledge transfer activities (Perkmann et al., 2013). However, these types of activities did not appear to motivate Entrepreneurial Academics to engage with industry. This could be suggested to be caused by the time and resources required from academics to attend these type of relational events where it is often hard for academics to quantify benefit, particularly in the short term, with respect to career progression. This finding stressed that knowledge transfer mangers need to recognise the importance of motivating academics to engage in these modes of knowledge transfer to more fully engage with industry at multiple levels and thus contribute towards universities ability to engage in open innovation activities with quadruple helix stakeholders. This may require creating incentives for academics to participate in these activities at a faculty level, with a need for university promotional mechanisms to recognise academic involvement in activities which contribute to the long term engagement with industry (Dowlng Report, 2015).

Joint Conferences appeared to be the best motivator for entrepreneurial academics. Alexander and Childe (2011) identify that joint conferences facilitate the ability to build up relationships and often were open in their nature and lead to long term relationships. Therefore they were perceived attractive by academics by offering a balanced return on time invested and rewards reaped by academics, over other activities such as the Networking modes of collaboration. 
Joint Supervision was found to present low levels of motivation for academics despite it stimulating openness and creating relational engagement. However, one new mode ${ }^{1}$ of engagement, Knowledge Transfer Partnerships were found to be the exception since they provided quite high motivation levels compared to their counterparts, Master-level and industrial post-doctoral projects. Similarly, not all forms of secondment are attractive to academics, with funded-chairs being the exception. The other variants of secondments do not appear to reward the individual academics even though they are relational and open.

Patents and Licensing along with Joint Ventures and New Venturing were not found to motivate Entrepreneurial Academics; however, this is to expected if we consider the fundamental differences in the definitions between the Academic Entrepreneurs and the Entrepreneurial Academics (Perkmann et al., 2013) and further represents the continuum between the two concepts (as shown in figure 1). These types of engagement rank as neither relational nor open (Alexander and Martin, 2013). This finding has implications for knowledge transfer managers, signalling the need to explore ways of opening up the wide spectrum of knowledge transfer channels to engage more fully with industry in line with open innovation policy (Witty, 2013; Dowling Report, 2015).

Lastly, Collaborative Research appear to be both relational and open and ranks as reasonably motivating for academics, who are rewarded in a number of ways for engaging in this activity. This is consistent with the openness and the relational nature of this activity and concurs with prior research identifying research related activities being core motivators for entrepreneurial academics (Bichnel et al., 2010).

\section{Conclusions, Contributions and Research Limitations}

This research aimed to offer practical insights on whether the 'new' modes of engagement increasingly offered by universities really address the policy drivers for open innovation. Furthermore, this research explored whether these activities motivated Entrepreneurial Academics. From the preliminary findings, it is evident that universities are engaging in a wide range of collaborative activities in a bid to engage more fully with quadruple helix stakeholders however, these engagement activities appeared to be variations or 'repackaged' versions of existing knowledge transfer activities. Even with the increasing pressure on universities to engage more fully with industry and end users (RIS, 2014) the collaboration activities identified did not present any truly novel or new ways of engagement in order to stimulate university- industry collaboration and impact.

\footnotetext{
${ }^{1}$ We note that this research refers to Knowledge Transfer Partnerships as new modes of engagement but acknowledge that this particular mode of engagement has been undertaken for approximately 40 years.
} 
The findings suggested that the additional modes of engagement did not sufficiently represent anything that is more 'open' than previous offerings. Therefore, whilst innovation policy stresses the need for universities to engage more fully with industry and end users within their business models (Witty, 2013; Miller et al., 2014; Dowling Report, 2015), little appears to be changing. Furthermore, the findings revealed that that out of the 32 collaborative activities, only 8 appeared to motivate an Entrepreneurial Academic. This may have significant implications on the ability of universities to truly become open. Thus, concurring with Becknell et al. (2010) and Lockett et al., (2008) there is a need for more attention needs to be given to effective ways to motivate Entrepreneurial Academics to engage with industry and end-users. For a fully functioning quadruple helix, there needs to be 'buy in' from all stakeholders involved, not just at macro levels but particularly within micro levels, such as academics (Miller et al., 2014).

Within policy and practice there is an increasing emphasis on open technology commercialisation processes as a way of stimulating economic growth, where it is said to result in co-creational value between universities, industry and end users (Stevens and Bagby, 2001; Arnkil et al., 2010; Carayannis and Rakhmatullin). However, this research identified that patenting, licensing, joint ventures and new ventures were closed activities which in turn did not motivate the Entrepreneurial Academic. These findings suggests that universities are not fully aligning their activities to policy drivers and continuing to maintain relatively closed technology commercialisation processes (Schoonmaker and Carayannis, 2013).

This paper makes the following contributions. Firstly this paper extends understanding of the concept of Entrepreneurial Academic and Academic Entrepreneur by considering the relative motivations for Entrepreneurial Academic's industry engagement activities. Second, this research furthers theory and practice by stressing the role of micro level actors, namely academics in contributing towards universities ability to embrace more open innovation practices. Third, this research contributes to the understanding of which types of university engagement satisfy the drivers for open innovation as dictated by government policy. Fourth, this research has practical implications (for University senior managers, or knowledge brokers and intermediaries) by providing insights into how university offerings can contribute or detract from the open innovation imperative. Lastly, findings will aid practitioners in understanding how they can stimulate the participation of academics to become Entrepreneurial Academics within their organisations.

This research was exploratory in nature thus the methodology may not be as robust as it could be due to not differentiating between universities of different type (such as enterprise-led or teaching-led vs. research-led) nor do we differentiate between academic staff in terms of their primary role (such as Education \& Scholarship vs. Education \& Research). Future research is needed to explore the entrepreneurial 
academic concept in practice, taking into account university type, academic role and performance indicators. This research gives insights into the challenges universities face in embracing open commercialisation activities and models however, further research is needed to explore how universities can depart from the established norms around protecting and licencing intellectual property. Furthermore, the data collected does not lend itself to generalisation, however, based on the findings, two tentative hypotheses, which could fuel further research to more fully understand the impact the type collaboration activities may have on the motivation of different types of academics. These hypothesis are as follows:

H1 - Entrepreneurial Academics are motivated to become involved in relationalstyle engagements, which are achieved in the knowledge transfer channels that stimulate open innovation.

H2 - Academic Entrepreneurs are motivated to become involved in transactional style engagement, which are epitomised by careful protection of Intellectual Property, the sale of Patents and new venture creation and which predicate closed cycles of innovation.

With a better understanding between the relationship between research-led knowledge transfer activities and the more transactional commercial activities, universities could finally align their strategic vision (whether it be to be researchled and to employ a blend of high quality researchers working alongside Entrepreneurial Academics or to be teaching or enterprise-led and employing high quality teaching staff working alongside academic entrepreneurs). This in turn could end the organisational cycling between partnering vs. contacting; in-house research and enterprise vs. arms-length organisations; or unified research and knowledge transfer services vs. arbitrary research and enterprise departments. This would enable balanced decisions to be made on resourcing and the subsequent architectures and governance of their respective knowledge or technology transfer departments..

Furthermore, this paper introduces and demonstrates the efficacy of analytical tools that could be further developed to facilitate the comparing, contrasting and evaluating knowledge transfer and open innovation intermediary services.

However, a wider and more systematic review of the literature is needed, coupled with employing a grounded-theory style, round of passive data collection across a large number of universities to help refine and test these tools. With further research, management guidelines could be developed to aid different institutions in motivating their academics, which could build on the preliminary contribution identified within this paper.

\section{References}


AGRAWAL, A., K 2001. University to Industry Knowledge Transfer: Literature review and unanswered questions. International Journal of Management Reviews, 3, 285-302.

ALEXANDER, A., T \& CHILDE, S., J. 2011. A Framework for Knowledge Transfer. In: Advances in Production Management Systems, 2011 Stavanger, Norway. Springer.

ALEXANDER, A., T, PEARSON, S., R, FIELDING, S., N \& BESSANT, J., R 2012. The Open Innovation Era - Are University Services up to the Challenge? In: BITRAN, I. \& CONN, S. (eds.) The XXIII ISPIM Conference - Action for Innovation: Innovating from Experience Barcelona, Spain: Wiley \& Sons.

ALEXANDER, A. T. \& CHILDE, S. J. 2012. Innovation: a knowledge transfer perspective. Production Planning \& Control, 1-18.

ALEXANDER, A. T. \& MARTIN, D. P. 2013. Intermediaries for open innovation: A competence-based comparison of knowledge transfer offices practices. Technological Forecasting and Social Change, 80, 38-49.

ARNKIL, R. JARVENSIVU, V., KOSKI, P. \& PIJRAINEN, T. 2010. Exploring Quadruple Helix. Outlining User-orientated innovation models. Working paper, University of Tampere, Institute for Social research, Work research Centre.

ASHEIM, B.T. \& COENEN, L. 2005. Knowledge bases and regional innovation systems: comparing Nordic clusters. Research Policy, 34 (8), 1173-90.

BERCOVITZ, J. \& FELDMAN, M., 2008. Academic entrepreneurs: organizational change at the individual level. Organization Science 19, 69-89

BICKNELL, A., FRANCIS-SMYTHE, J. \& ARTHUR, J. (2010) Knowledge Transfer: De-constructing the Entrepreneurial Academic. International Journal of Entrepreneurial Behaviour and Research, 16 (6), 485-501.

CARAYANNIS, E.G. \& RAKHMATULLIN, R. 2014. The Quadruple/Quintuple Innovation Helixes and Smart Specialisation Strategies for Sustainable and Inclusive Growth in Europe and Beyond. Journal of the Knowledge Economy, $\mathbf{5}$ (2), 212-239.

CARAYANNIS, E. G. \& CAMPBELL, D. F. 2012. Mode 3 knowledge production in quadruple helix innovation systems, Springer.

CARAYANNIS, E.G. and CAMPBELL, D.F.J. 2009. "Mode 3" and "Quadruple Helix": toward a 21 st century fractal innovation ecosystem. International Journal of Technology Management, 46 (3/4), 201-234.

CHESBROUGH, H. 2006. Open Innovation: A New Paradigm for Understanding Industrial Innovation," in CHESBROUGH, H. VANHAVERBEKE, W. \& WEST, J. (eds.) Open Innovation: Researching a New Paradigm. Oxford: Oxford University Press, 1-12.

CHESBROUGH, H. 2003. Open Innovation: The New Imperative for Creating and Profiting from Technology, Boston, Harvard Business School Press.

CHESBROUGH, H. 2010. Business model innovation: Opportunities and barriers. Long Range Planning. 43, 354-363.

COLAPINTO, C. \& PORLEZZA, C. 2012. Innovation in Creative Industries: From the Quadruple Helix Model to the Systems Theory. Journal of the Knowledge Economy, 3 (4), 343-33.

D'ESTE, P. \& PERKMANN, M. 2011. Why do academics engage with industry? The entrepreneurial university and individual motivations. The Journal of Technology Transfer 36, 316-339.

ENKEL, E., GASSMANN, O. \& CHESBROUGH, H. 2009. Open R\&D and open innovation: exploring the phenomenon. $R \& D$ Management, 39, 311-316 
ETZKOWITZ, H. 2002. The triple helix of university-industry-government: Implications for policy and evaluation Report 2002:11. Stockholm: SISTER Swedish Institute for Studies in Educations.

GALBRAITH, B. \& McAdam, R. 2013. The convergence of ICT, policy, intermediaries and society for technology transfer: evidence from European innovation projects. Technology Analysis and Strategic Management, 25 (3), 249-252.

GOKTEPE, D. \& MAHANGAONKAR, P. 2008. What do scientists want: money or fame? Jena Economic Research Papers.

GRIMALDI, R., KENNEY, M., SIEGEL, D. S. \& WRIGHT, M. 2011. 30 Years after Bayh-Dole: Reassessing Academic Entrepreneurship. Research Policy, 40 (8), 1045-1057.

HEWITT-DUNDAS, N. 2012. Research intensity and knowledge transfer activity in UK universities. Research Policy, 41, 262-275.

HOLI, M., FRANKLIN, R., HUGO, E. \& LAPINSKI, J. 2007. An analysis of UK university technology and knowledge transfer activities. 1, 1-2.

HOLI, M., T, WICKRAMASINGHE, R. \& VAN LEEUWEN, M. 2008. Metrics for the evaluation of knowledge transfer activities at Universities. London: Library House.

HOHMAN, C. \& FULLER, J. 2010. An analysis of the techniques of technology transfer. Journal of Applied Business Research, 26 (6) 1-11.

HOWARD, J. 2005. The Emerging Business of Knowledge Transfer - creating value from intellectual products and services. In: DEPARTMENT OF EDUCATION, S. A. T. (ed.).

HOWELLS, J. 2006. Intermediation and the role of intermediaries in innovation. Research Policy, 35 (7), 715-728.

HUGHES, A. 2010. The Multi-faceted role of universities. ESRC Society Now. Swindon: Economic \& Social Research Council.

HUIZINGH, E.K.R.E. 2011. Open Innovation: State of the Art and Future Perspectives. Technovation, 31 (1), pp. 2-9.

JENSEN, R. \& THURSBY, M. 2001. Proofs and Prototypes for Sale: The Licensing of University Inventions. American Economic Review, 91 (1), 240-259.

KENNEY, M. \& MOWERY, D.C. (2014) Public Universities and Regional Growth: Insights from the University of California. Stanford University Press.

LAWLER, C. (2011) The capitalisation of knowledge: a triple helix of university-industry government. Studies in Higher Education, 36, 746-747.

LEE, Y. S. 2000. The sustainability of university-industry research collaboration: An empirical assessment. Journal of Technology Transfer, 25 (2), 111-133.

MACGREGOR, S.P. MARQUES-GOU, P. \& SIMON-VILLAR, A. 2010. Gauging Readiness for the Quadruple Helix: A Study of 16 European Organisations. Journal of the Knowledge Economy, 1 (3), 173-190.

MARTINELLI, A., MEYER, M., VON TUNZELMANN, N. 2008. Becoming an entrepreneurial university? A case study of knowledge exchange relationships and Faculty attitudes in a medium-sized, research-oriented university. Journal of Technology Transfer, 33, 259-283.

MCADAM, R., MILLER, K., MCADAM, M. and TEAGUE, S. 2012. The development of University Technology Transfer stakeholder relationships at a regional level: lessons for the future. Technovation, 32 (1), 57-67.

MEYER, M. 2003. Academic entrepreneurs or entrepreneurial academics? Researchbased ventures and public support mechanisms. R\&D Management, 33, 107-115 
MEYER-KRAHMER, F., SCHMOCH, U., 1998. Science-based technologies: universityindustry interactions in four fields. Research Policy, 27(8), 835-851

MILLER, K., MCADAM, M. \& MCADAM, R. 2014. The University Business Model: Evolution and Emergence from a Stakeholder Perspective. $R \& D$ Management, 44, 265-287.

PERKMANN, M. \& WALSH, K. 2007. University-industry relationships and open innovation: towards a research agenda. International Journal of Management Reviews, 9 (4), 259-280.

PERKMANN, M., TARTARI V., MCKELVEY M., AUTIO E., BROSTROM, A., D’ESTE, P., FINI, R., GEUNA, A.; GRIMALDI, R., HUGHES, A., KRABEL, S., KITSON, M., LLERENA, P., LISSONI, F. SALTER, A. \& SOBRERO, M. 2013. Academic engagement and commercialisation: A review of the literature on university -industry relations. Research Policy, 42 (2), 423-442.

PLEWA, C., RAMPERSAD, G., JOHNSON, C.R., BAAKEN, T., MACPHERSON, G. \& KORFF, N. (2013). The evolution of university-industry linkages-A framework. Journal of Engineering and Technology Management, 30 (1), 21-44.

PONOMARIOV, B., BOARDMAN, P.C., 2008. The effect of informal industry contacts on the time university scientists allocate to collaborative research with industry. The Journal of Technology Transfer, 33, 301-313

RIS 2014. National/Regional Innovation Strategies for Smart Specialisation. Cohesion Policy 2014-2020, European Commission. Available online: http://ec.europa.eu/regional_policy/sources/docgener/informat/2014/smart_speci alisation en.pdf (accessed 10/02/2014).

ROTHAERMEL, F.T., AGUNG, S.D. \& JIANG, L. 2007. University entrepreneurship: A taxonomy of the literature. Industrial and Corporate Change, 16 (4), 691-791.

SCHOONMAKER, M. and CARAYANNIS, E. 2013. Mode 3: A Proposed Classification Scheme for the Knowledge Economy and Society. Journal of the Knowledge Economy, 4 (4), pp. 556-577.

SHIBAYAMA, S. 2012. Conflict Between Entrepreneurship and Open Science, and the Transition of Scientific Norms. Journal of Technology Transfer, 37 (4), 508-531.

OECD 1997. National Innovation Systems Paris: Organisation for Economic Cooperation \& Development.

PACEC 2012. Strengthening the contribution of English Higher Education Institutions to the Innovation System: Knowledge Exchange and HEIF Funding. In: HEFCE (ed.). Cambridge: PACEC.

PERKMANN, M. \& WALSH, K. (eds.) 2008. How firms source knowledge from universities: Partnerships versus contracting Cheltenham: Edward Elgar.

SCHARTINGER, D., RAMMER, C., FISCHER, M. \& FROHLICH, J. 2002. Knowledge interactions between universities and and industry in Austria: Sectoral patterns and determinants. Research Policy, 31.

SEIGEL, D., S, WALDMAN, D., A, ATWATER, L., E \& LINK, A. 2004. Toward a model of the effective transfer of scientific knowledge from academicians to practitioners: qualitative evidence from the commercialisation of university technologies. Journal of Engineering Technology Management, 21, 115-142.

STEVENS, J., M \& BAGBY, J., W 2001. Knowledge transfer from universities to business: returns for all stakeholders Organisation, 8, 259-268.

TORNATZKY, L., WAUGAMAN, P. G. \& GRAY, D. O. 2002. Innovation U:New University Roles in a Knowledge Economy. In: COUNCIL, S. T. (ed.).

VAN LOOY, B., LANDONI, P., CALLERT, J., VAN POTTELSBERGHE, B., SAPSALIS, E. \& DEBACKERE, K. 2011. Entrepreneurial effectiveness of 
European universities: An empirical assessment of antecedents and trade-offs. Research Policy, 40 (4), 553-564.

YIN, R. K., 2011. Case study research: Design and methods (4th ed). Thousand Oaks, CA: Sage. 